\title{
Succinate Dehydrogenase [Ubiquinone] Cytochrome B Small Subunit, Mitochondrial
}

National Cancer Institute

\section{Source}

National Cancer Institute. Succinate Dehydrogenase [Ubiquinone] Cytochrome B Small Subunit, Mitochondrial. NCI Thesaurus. Code C97781.

Succinate dehydrogenase [ubiquinone] cytochrome b small subunit, mitochondrial (159 $\mathrm{aa}, \sim 17 \mathrm{kDa}$ ) is encoded by the human SDHD gene. This protein plays a role in the regulation of the electron transport chain. 